\title{
Model Pembelajaran Pendidikan Kewarganegaraan Sebagai Pendidikan Nilai Moral di Sekolah Dasar
}

\author{
Nurfaizah A.P. \\ Studi PGSD Fakultas Ilmu Pendidikan Universitas Negeri Makassar \\ a.p_nurfaizah@yahoo.com
}

\begin{abstract}
Seeing the condition of many moral values, so the role of teachers / educators and designers in the field of values and moral education is necessary. The problem that arises is how can values and moral education be communicated to the students and which learning model is appropriate? Citizenship Education is one form of values education, which in the delivery of learning needs to show some models. Some models of values and education will help us understand moral education and help students practice practicing the moral values they learn in school.
\end{abstract}

Keyword: Citizenship Education, values education

\section{PENDAHULUAN}

Era globalisasi yang ditandai dengan kecanggihan teknologi dan komunikasi dewasa ini, dimana hubungan antar bangsa sudah demikian erat maka konsekuensinya adalah setiap bangsa harus membuka diri jika tidak ingin ditinggal oleh kemajuan bangsa-bangsa lain, demikian pula halnya dengan Indonesia. Usaha untuk meletakkan dasar-dasar masyarakat modern Indonesia tidak saja menyerap modal, teknologi, ilmu pengetahuan dan keterampilan dari luar, akan tetapi terbawa pula nilai-nilai sosial politik yang berasal dari kebudayaan lain, makin deras mengalir sejalan dengan kebebasan yang dengan sadar kita buka. Hal tersebut merupakan tantangan bagi pembinaan kelestarian kepribadian bangsa yang berlandaskan nilai moral dan norma spiritual, afektual dan metafisis. Stok dan kualifikasi kepribadian bangsa terancam erosi dan menuju pada proses dehumanisasi yang kian menipis dan terlapisi oleh konsep nilai dan moral serta norma lain atau norma baru.

Kenyataan tersebut di atas akan mempengaruhi sikap dan perilaku masyarakat khususnya remaja dan anak-anak. Mereka tidak tahu membedakan mana nilai moral yang merupakan kepribadian bangsa yang patut untuk dianut dan mana yang tidak patut dianut. Nilai moral seperti rela berkorban, berani dan jujur membela kebenaran, menggunakan bahasa Indonesia yang baik dan benar, cinta produksi dalam negeri menjadi kabur oleh konsep nilai, moral dan norma lain atau norma baru (Nurfaizah: 2004).
Kenyataan menunjukkan bahwa akhirakhir ini makin marak tindakan yang mencerminkan kemerosotan moral bangsa. Merebaknya isu-isu moral dikalangan anakanak dan remaja seperti penggunaan narkoba, tawuran, pornografi, pemerkosaan, perjudian, pembunuhan, geng motor dan sebagainya, sudah menjadi masalah sosial yang sampai saat ini belum dapat diatasi secara tuntas. Akibat yang ditimbulkannya cukup serius dan tidak dapat dianggap sebagai suatu persoalan sederhana, karena tindakan-tindakan tersebut sudah menjurus kepada tindakan kriminal (Budiningsih: 2004).Kondisi ini sangat memprihatinkan masyarakat khususnya para orang tua, para guru (pendidik) dan masyarakat sebab pelaku-pelaku beserta korbannya adalah kaum remaja, terutama mahasiswa, pelajar bahkan murid-murid SD.

$$
\text { Melihat kondisi banyaknya }
$$

penyimpangan dikalangan anak-anak dan remaja merupakan salah satu dampak dari rendahnya pemahaman terhadap nilai-nilai moral Pancasila, sehingga peranan guru/ pendidik dan perancang dibidang pendidikan moral, sangatlah diperlukan. Persoalan yang muncul adalah bagaimana pendidikan nilai moral disampaikan kepada murid dan model pembelajaran mana yang tepat digunakan?

Pendidikan nilai dan moral merupakan pondasi yang kokoh dan sangat penting keberadaannya, dan jika hal itu telah tertanam serta terpatri dengan baik dalam setiap insan sejak dini, hal tersebut merupakan awal yang baik bagi pendidikan anak bangsa untuk menjalani pendidikan selanjutnya. Bangsa 
Indonesia sangat menjunjung tinggi nilai-nilai moral . Nilai-nilai luhur ini pun dikehendaki menjadi motivasi spiritual bagi bangsa ini dalam rangka melaksanakan sila-sila lainnya dalam pancasila (Hidayat: 2007 ).

\section{KAJIAN PUSTAKA}

Pengertian nilai dan Pendidikan Nilai

Nilai menurut Djahiri (1999), adalah harga, makna, isi dan pesan, semangat atau jiwa yang tersurat dan tersirat dalam fakta, konsep dan teori sehingga bermakna secara fungsional. Nilai berfungsi unuk mengarahkan, mengendalikan dan menentukan kelakuan seseorang, karena nilai dijadikan standar perilaku. Menurut Diktionary (Winataputra: 1989), nilai adalah harga atau kualitas sesuatu, artinya sesuatu dianggap memiliki nilai apabila secara intrinsik memang berharga. Selanjutnya pendidikan nilai adalah pendidikan yang mensosialisasikan dan menginternalisasikan nilai-nilai kedalam diri anak didik. Pelaksanaan pendidikan nilai selain dapat melalui taksonomi Bloom dkk, dapat juga menggunakan jenjang afektif (Kratzwohl:1967) berupa penerimaan (Receiving), penanggapan (responding), penghargaan (Valuing), pengorganisasian (organization), karakterisasi (characteri-zation). Dalam pembelajaran PKn $\mathrm{SD}$, nilai sangat penting untuk ditanamkan secara dini karena nilai bermanfaat sebagai standar pegangan hidup.

\section{Pengertian Moral dan Pendidikan Moral}

Menurut Lillie, moral berasal dari kata mores (bahasa latin) yang berarti tata cara dalam kehidupan atau adat istiadat. Dewey mengatakan bahwa moral sebagai hal-hal yang berhubungan dengan nilai-nilai susila, sedangkan Baron dkk (1980) mengatakan bahwa moral adalah hal-hal yang berhubungan dengan larangan dan tindakan yang membicarakan salah atau benar. Oleh Suseno (1987) dikatakan bahwa moral selalu mengacu pada baik buruknya manusia, sehingga bidang moral adalah bidang kehidupan manusia dilihat dari segi kebaikannya sebagai manusia. Selanjutnya Suseno mengemukakan sikap moral yang sebenarnya disebut moralitas. Ia mengartikan moralitas sebagai sikap hati orang yang terungkap dalam indakan lahiriah. Moralitas terjadi apabila orang mengambil yang terbaik karena ia sadar akan kewajiban dan tanggung jawabnya bukan karena ia mencari keuntungan. Jadi moralitas adalah sikap dan perbuatan baik yang betul-betul tanpa pamrih. Hanya moralitaslah yang bernilai moral (Suseno: 1987). Setiap orang pasti mempunyai moral, tetapi belum tentu setiuap orang berpikiran kritis tentang moralnya. Pemikiran yang kritis tentang moral inilah yang disebut etika (Darmodihardjo:1996). Menurut Setiadi (2003) moral adalah ajaran tentang baik dan buruk perbuatan dan kelakuan (akhlak). Jadi moral adalah tingkah laku manusia yang dilakukan dengan sadar, dipandang dari sudut baik dan buruknya dalam kehidupan bermasyarakat, berbangsa dan bernegara.

Sedangkan pendidikan moral adalah pendidikan untuk menjadikan anak manusia bermoral baik dan manusiawi. Sedangkan menurut Ouska dan Whellan (1997), moral adalah prinsip baik buruk yang ada dan melekat dalam diri individu / seseorang. Walaupun moral itu berada dalam diri individu, tetapi moral berada dalam suatu system yang berwujud aturan. Moral dan moralitas memiliki sedikit perbedaan, karena moral adalah prinsip baik buruk, sedangkan moralitas merupakan kualitas pertimbangan baik buruk. Dengan demikian hakikat dan makna moralitas bisa dilihat dari cara individu yang memiliki moral dalam mematuhi maupun menjalankan aturan.

Berkaitan dengan beberapa pengertian tentang moral tersebut di atas, Winataputra (1987) mengemukakan bahwa pendidikan moral berkaitan dengan pertanyaanpertanyaan benar dan salah dalam hubungan interpersonal yang melibatkan konsep-konsep. Konsep yang dimaksud adalah tentang hak Asasi manusia,harkat dan martabat manusia, keadilan, pertimbangan, persamaan dan hubungan timbal balik. Selanjutnya dijelaskan pula tentang tujuan pendidikan moral, adalah sebagai proses membantu murid untuk lebih meningkatkan tanggung jawab, adil, dan pertimbangan yang matang terhadap dan tentang orang lain.

\section{Unsur-Unsur Pembelajaran Moral}

Ruminiati (2007) menyatakan bahwa ada beberapa pakar yang mengembangkan pembelajaran nilai moral dengan tujuan membentuk watak atau karakteristik anak. Pakar-pakar tersebut diantaranya adalah Newman, Simon, Howe, Dan Lickona. Dari beberapa pakar tersebut, pendapat lickona yang lebih cocok untuk membentuk watak atau karakter anak. Pandangan lickona (1992) tersebut dikenal dengan educating for character atau pendidikan karakter/watak untuk membangun karakter atau watak anak. 
Dalam hal ini, lickona mengacu pada pemikiran filosof Michael Novak yang berpendapat bahwa watak atau karakter seseorang dibentuk melalui 3 aspek yaitu, moral knowing, moral feeling, dan moral behavior, yang satu sama lain saling berhubungan dan terkait.

Lickona menggaris bawahi pemikiran Novak. Ia berpendapat bahwa pembentukan karakter atau watak anak dapat dilakukan melalui 3 kerangka pikir, yaitu konsep moral (moral knowing), sikap moral (moral feeling), dan perilaku (moral behavior). Dengan demikian, hasil pembentukan sikap karakter anak pun dapat dilhat dari 3 aspek,yaitu konsep moral, sikap moral, dan perilaku moral.

Berdasarkan hal tersebut di atas, dapat disimpulkan bahwa pengertian moral/moralitas adalah suatu tuntunan perilaku yang baik yang dimiliki oleh individu sebagai moralitas, yang tercermin dalam pemikiran/konsep, sikap dan tingkah laku. Dalam pembelajaran PKn, moral sangat penting untuk ditanamkan pada anak usia SD, karena proses pembelajaran PKn SD memang bertujuan untuk membentuk moral anak, yaitu moral yang sesuai dengan nilai falsafah hidupnya.

Lickona (Suparno,dkk:2002) menekankan pentingnya memperhatikan tiga unsur dalam menanamkan nilai moral, yaitu pengertian atau pemahaman moral, perasaan dan tindakan moral. Ketiga unsur ini saling berkaitan, oleh karena itu guru perlu memperhatikan ketiga unsur tersebut agar nilai moral yang ditanamkan tidak sekadar sebagai pengetahuan saja tetapi benar-benar menjadi tindakantindakan yang moral.

Pengertian dan pemahaman moral adalah kesadaran moral, rasionalitas moral atau alasan mengapa seseorang harus melakukan hal itu, suatu pengambilan keputusan berdasarkan nilai-nilai moral. Pengertian dan pemahaman moral seringkali disebut sebagai penalaran moral atau pemikiran moral atau pertimbangan moral, yang merupakan segi kognitif dari nilai moral. Segi kognitif ini perlu diajarkan kepada murid agar dapat mengerti mengapa suatu nilai perlu dilakukan.

Perasaan moral, lebih kepada kesadaran akan hal-hal yang baik dan tidak baik. Perasaan mencintai kebaikan dan sikap empai kepada orang lain merupakan ekspresi dari perasaan moral. Perasaan moral ini sangat mempengaruhi seseorang untuk berbuat baik. Oleh sebab itu perasaan moral perlu diajarkan dan dikembangkan dengan memupuk perkembangan hari nurani dan sikap empati.
Tindakan moral yaitu kemampuan untuk melakukan keputusan dan perasaan moral ke dalam perilaku-perilaku nyata. Tindakan moral ini perlu difasilitasi agar muncul dan berkembang dalam pergaulan sehari-hari. Lingkungan sosial yang kondusif untuk memunculkan tindakan moral sangat diperlukan dalam pembelajaran moral. Kohlberg (1977) menyatakan bahwa penalaran atau pemikiran moral merupakan faktor penentu yang melahirkan perilaku moral. Oleh karena itu untuk menemukan perilaku moral yang sebenarnya dapat ditelusuri melalui penalarannya, artinya pengukuran moral yang benar tidak sekadar mengamati perilaku moral yang tampak, tetapi harus melihat pada penalaran moral yang mendasari keputusan perilaku moral tersebut.

Selanjutnya untuk mengembangkan pendidikan moral bagi murid, diperlukan modifikasi unsur-unsur moral dengan faktorfaktor budaya dimana anak tinggal. Program pembelajaran moral seharusnya disesuaikan dengan karakteristik murid tersebut, kaitannya dengan penalaran moral, perasaan moral dan tindakan / perilaku moral.

Wahab (1997) mengemukakan bahwa untuk memudahkan guru dalam melaksanakan pembelajaran moral di SD, beberapa karakteristik murid SD yang penting diketahui guru dalam kaitannya dengan model dan media pembelajaran di SD yaitu: a) Satuan pendidikan di SD dapat dibagi kedalam dua bagian besar yaitu kelas rendah dan kelas tinggi, b) Murid SD cenderung untuk bermain sambil belajar, c) pengetahuan yang perlu dimiliki adalah pengetahuan dan pengertian yang sederhana, d)Pengajaran lebih menekankan pada pengalaman dan pembiasaan, dan e) Pengalaman belajar yang baik adalah yang sarat dengan nilai.

\section{PEMBAHASAN}

\section{Model Pembelajaran Nilai- Moral Di SD}

Pendidikan Kewarganegaraan (PKn) adalah salah satu bentuk pendidikan nilai dan moral yang dalam penyampaiannya perlu ditampilkan beberapa model pendidikan moral. Beberapa model pendidikan moral akan membantu kita memahami pendidikan moral dan sekaligus membantu murid berlatih mengamalkan nilai-nilai moral Pancasila yang dipelajarinya di sekolah. Winataputra (1987) mengemukakan bahwa untuk membantu pemahaman umum tentang perspektif model pendidikan moral maka terlebih dahulu harus dipahami hubungan antara perhatian 
/kepedulian(Carring),menilai/mempertimbang kan (Judging), dan tindakan (acting).

Perhatian/kepedulian (carring) menunjukkan perilaku seseorang untuk menolong atau memperhatikan orang lain yang didorong oleh suatu tingkat perasaan tertentu. Menilai/mempertimbangkan (judging) memperhatikan atau menolong orang lain tidak terlepas dari nalar. Dengan nalar atau pertimbangan suatu masalah moral sering menempatkan kesejahteraan orang lain menjadi taruhan. sedangkan tindakan (acting) sebagai moral adalah kualias perhatian atau pertimbangan yang memandunya. Walaupun tindakan bukan suatu kategori moral, namun tanpa kesempatan untuk bertindak, akan menghambat proses perkembangan moral. Selanjutnya Winataputra (1987) mengemukakan bahwa dengan memahami ketiga model proses di atas (carring,jodging acting) akan membantu pemahaman kita tentang perspektif masing-masing model pendidikan moral.

Khusus mengenai pendidikan moral, Simon,dkk (1972) mengajukan lima model umum yakni:(a) Model Penanaman Moral atau Moral Inculcation dengan asumsi bahwa dalam setiap masyarakat terdapat suatu paket nilai atau moral yang secara terus menerus telah diperaktekkan dan di tes melalui pengalaman. Atas asumsi itu maka murid harus dibekali dengan paket nilai moral melalui proses transper secara langsung bagi setiap orang. (b) Model Transmisi nilai.Melalui sikap bebas bahwa tidak ada sistem nilai, moral yang baik bagi setiap orang. atas dasar itu maka seyogiaya diberi kebebasan untuk berpikir dan menetapkan sendiri apa yang akan dilakukannya tanpa campur tangan dari orang dewasa. Namun salah satu kelemahan model ini adalah terlalu bebas dan melupakan kenyataan bahwa dalam setiap masyarakat terdapat sistem nilai yang diterima dan dijunjung tinggi bersama. (c) Model Tauladan atau Modeling dengan asumsi yang penting bagi seorang guru seharusnya menampilkan dirinya sendiri sebagai tauladan. Murid akan melihat sendiri perilaku dan nilai yang dijunjung tinggi oleh guru dan pada akhirnya akan mengadopsi nilai dan perilaku itu melalui proses imitasi secara sadar. (d) Model Klarifikasi Nilai yang berolak pada Valuing dimana murid memegang kepercayaan dan membangun perilaku atas kepercayaan itu. Model itu memiliki tujuh proses yaitu Bangga atas kepercayaan dan perilaku yang menunjukkan perasaan senang dan bangga dan menyatakan pada orang lain,memilih kepercayaan dan perilaku yang memilih dari berbagai alternatif, memilih setelah menguji dan mempertimbangkannya, memilih dengan leluasa dan bebas, bertindak atas dasar kepercayaan itu dan berindak atas dasar suatu pola secara berulang-ulang dengan tetap konsisten. (e) Model Klarifikasi Nilai yang diintegrasikan ke dalam esensi mata pelajaran. Cara ini mengaitkan proses klarifikasi nilai dengan strategi mempelajari isi mata pelajaran dan keterampilan dalam rangka meningkatkan kemampuan membangun pengetahuan, membangun nilai dan sistem nilai.

Berdasarkan alternatif model sebagaimana dikemukakan di atas, Winataputra (1989) mengelompokkan model-model itu menjadi:

\section{Model yang berorientasi pada penalaran moral.}

Esensi tujuan pendidikan moral ialah pemahaman dan penghayatan terhadap nilai moral. Dimensi pemahaman yang merupakan bagian integral dari proses penalaran atau proses kognitif merupakan salah satu prasyarat bagi tumbuhnya proses penghayatan nilai/moral, yang pada akhirnya akan melandasi perilaku moral sebagaimana yang diposulatkan oleh Piaget dan Kohlberg.Yang termasuk ke dalam kelompok ini ialah modelmodel pengelolaan informasi Joice dan Weil (1986) dengan menekankan pada konsep dan nilai moral Pancasila. Model klarifikasi ini menitik beratkan pada proses penalaran mengenai isu moral dalam kehidupan seharihari. Model ini bertujuan meningkatkan taraf moralitas, dan kemampuan penalaran tingkat tinggi yang diharapkan dapat memberikan rujukan dasar bagi perilaku moral individu. Model ini dirancang untuk membantu murid mempelajari konsep-konsep yang dapat dipakai untuk mengorganisasikan informasi (pencapaian konsep nilai/moral), dirancang untuk melibatkan para murid dalam proses penalaran mengenai hubungan sebab akibat dan mengajukan pertanyaan, membangun konsep dan mengetes hipotesisis serta membantu para guru menyesuaikan proses belajar mengajar terhadap taraf kematangan murid dan untuk merancang cara-cara meningkatkan kecepatan perkembangan kognitif murid. 


\section{Model yang berorientasi pada interaksi sosial.}

Titik berat model ini pada proses latihan menghayati hakikat nilai/moral melalui proses pelibatan langsung dalam proses simulatif atau situasi sebenarnya. Model ini dirancang untuk membimbing murid mendefinisikan masalah, mengumpulkan data yang relevan mengembangkan dan mengetes hipotesis. Pada model ini murid dibimbing untuk memecahkan berbagai konflik, belajar mengambil peran orang lain dan mengamati perilaku sosial termasuk isu-isu kebijaksanaan umum atau konflik moral dalam kehidupan sehari-hari.

\section{Model yang berorientasi pada pembinaan pribadi.}

Esensi tujuan pendidikan moral yang didukung oleh model yang berorientasi pada pembinaan pribadi ialah penghayatan dan pengamalan nilai-nilai Pancasila. Proses penghayatan ini tidak terlepas dari proses penalaran karena itu penerapan model ini merupakan salah satu sarana bagi terbinanya pribadi murid yang mencerminkan esensi nilai moral. Pada model ini harus ditumbuhkan dalam diri murid kualitas pribadi yakni komitmen individu terhadap nilai-nilai moral. Para guru mencurahkan perhatian dan tenaganya untuk membantu murid memahami peranan utama dirinya, membantu memecahkan masalah yang dihadapi. Model ini dirancang untuk memberikan ransangan kreativitas, mendorong kerjasama dan memperkuat nilai sosial. Model ini berisi serangkaian kegiatan yang dapat mendorong timbulnya refleksi hubungan antar individu, citra diri, eksperimentasi dan penampilan diri. Model ini dirancang untuk membantu murid memikul tanggung jawab atas perilakunya dan lingkungan sosialnya sehingga dapat dilakukan di lingkungan kelasnya.

\section{Model yang berorientasi pada sistem perilaku.}

Esensi tujuan pendidikan moral yang didukung oleh model-model yang berorientasi pada sistem perilaku ialah pengamalan nilainilai moral Pancasila yang tentunya dilandasi oleh pemahaman dan penghayatan atas nilainilai moral Pancasila. Walaupun Piaget dan Kohlberg (1975) menyatakan bahwa perilaku tidaklah konstan karena bersifat kontekstual, akan tetapi perilaku yang dilandasi pemahaman dan penghayatan tentu dapat lebih utuh oleh karenanya pembinaan perilaku dianggap sama pentingnya dengan pembinaan kognisi dan sikap. Pada model ini murid diberi kemudahan untuk belajar bagaimana bertanggung jawab secara moral atas lingkungan personal dan social dan memahami dirinya secara utuh. Model ini digunakan untuk menciptakan lingkungan belajar yang produktif. Disamping itu banyak dipakai pada latihan keterampilan, misalnya bersimulasi sebagai pengendara yang mematuhi aturan lalu lintas sebagai salah satu bentuk perilaku moral.

Keempat kelompok model belajar mengajar tersebut di atas dapat dipilih oleh guru mana yang paling sesuai dan paling layak dipakai, disamping itu guru harus menguasai esensi tujuan pendidikan moral serta mengenal secara utuh karakteristik dari model yang dipilih. Termasuk didalamnya guru harus mengenal kekuatan Dan kelemahan dari setiap model dalam kaitannya dengan teori perkembangan moral.

\section{KESIMPULAN}

PKn sebagai salah satu bentuk pendidikan nilai/moral Pancasila di SD dapat menggunakan beberapa model belajar agar nilai-nilai moral yang ditanamkan kepada murid tidak sekadar sebagai pengetahuan saja tetapi benar-benar menjadi tindakan moral. Untuk mengembangkan pendidikan moral disekolah dasar (SD) guru harus memperhatikan unsur-unsur moral yakni pengertian atau pemahaman moral, perasaan moral, tindakan moral. Disamping itu program pembelajaran moral seharusnya disesuaikan dengan karakteristik dan budaya murid. Dari beberapa model yang ditampilkan ada yang benar-benar eksklusif, ada yang saling melengkapi dan ada yang tidak bersesuaian, namun kesemuanya dapat menjadi pustaka model yang dapat dipilih dalam menyelenggarakan pembelajaran moral. Pemilihan model-model tersebut akan banyak ditentukan oleh esensi moral dalam tujuan belajar yang ingin dicapai untuk setiap nilai Pancasila. Model yang satu mungkin lebih sesuai dengan butir nilai tertentu, sedangkan model lainnya hanya bisa dipakai untuk mencapai tujuan belajar butir tertentu juga.

\section{DAFTAR PUSTAKA}

BudiningsihAsri.C.2004. Pembelajaran Moral Berpijak pada Karakteristik Siswa dan Budayanya.Jakarta:Rineka Cipta.

Djahiri,Ahmad Kosasih.1992. Dunia Afektif, Nilai dan Moral. Bandung:Lab.PPMPFPIPS. 
Joice dan Weil.1986. Model of Teaching. New York:Helt Rincart \& Winson

Kholberg.1977. The Cognitive Developmental Approach to Moral Education. Curriculum Planning: A New Approach.Boston:Allyn and Bacon,Inc

Lickona,T.1992.Educating for Character.New York: Bantam Books.

Nurfaizah.2004. Peranan Pendidikan Pancasila dalam Membentuk Kepribadian Bangsa pada Era Globalisasi. Makalah. Makassar: seminar Nasional.

Ruminiati.2007.Pengembangan Pendidikan kewarganegaraan $S D$.

Setiadi M,Elly.2003. Panduan kuliah Pendidikan Pancasila Untuk Perguruan Tinggi.Jakarta: Gramedia Pustaka Utama.

Simon,dkk.1972.Values Clarivication, New York: Hart Publishing Co

Wahab Abdul Azis.1997.Pendidikan Pancasila dan Kewarganegaraan (PPKn). Jakarta: Depdikbud Dirjen Dikti Proyek Pengembangan Guru SD.

Winataputra,Udin S.1986.Konsep dan Strategi Pendidikan Moral Pancasila di Sekolah Menengah. Jakarta:Depdikbud. LPTK

Winataputra,Udin S.1990.Konsep dan Strategi Pendidikan Moral Pancasila (Suatu Penelitian Kepustakaan). Jakarta: Universitas Terbuka 